\title{
EXPERIENCE WITH THE ABC FOUNDATION SCHOOL OF MEDICINE UNDERGRADUATE MEETING
}

Angelo Bezerra Fede ${ }^{1}$, Michele da Costa Miranda², Andrea T. Lera², Aline Ueda², Daniela Veiga Antonangelo², Henrique de Lazari Schaffhausser², Auro del Giglio ${ }^{3 *}$ Study conducted at Faculdade de Medicina do ABC, Santo André, SP

*Correspondência:

Rua Mariana Correia 369

São Paulo - SP

CEP: 01444-000

sandrabr.netpoint.com.br

\begin{abstract}
SUMMARY
OBjective. To quantify the number of studies that were presented during oral sessions, selected for awards and published from 2002 to 2007 at the Undergraduate Medical Congress of ABC at the ABC Foundation School of Medicine.

METHODS. A retrospective systematic survey of papers selected for oral presentation and award at these undergraduate meeting from 2002 to 2007 was carried out by searching Medline and Lilacs databases and the annals of other medical meetings in order to ascertain which papers would eventually be published.

Results. From 2002 to 2007, 408 papers were selected for oral presentation and 71 (17.4\%) received at least one award. The total number of papers published was 138 (33.8\%), of which 33 (8.1\%) were in Medline, 57 (14\%) in Lilacs and $48(11.7 \%)$ in the annals of other scientific meetings. Receiving an award by the scientific committee was an independent variable for publication (OR: $2.0595 \% \mathrm{Cl}$ 1.22-3.46, $\mathrm{p}=0.006$ ) as well as for publication in Medline (OR: 2.62 95\% Cl $1.21-5.69, \mathrm{p}=0.01$ ). Conclusion. The institutional scientific production of undergraduate medical students presented in Undergraduate Medical Meetings is relevant and should continue to be stimulated.
\end{abstract}

KEY wORDS: Congresses. Publications. Meeting abstracts. Research.

\section{INTRODUCTION}

The first Undergraduate Medical Congresses appeared three decades ago in traditional medical schools throughout Brazil aiming to complement the scientific education of undergraduates by encouraging the undertaking of research projects. Over the years, these meetings became acknowledged by the Brazilian medical academia and part of the calendar of many Brazilian schools of medicine.

In most schools, the undergraduate medical meeting is organized by the students themselves. These students, with help from their colleagues and teachers, promote the formal presentation of scientific papers written by medical students under supervision of medical school teachers. A specifically assigned scientific committee, which includes some professors from other medical schools, selects the best papers for awards. Organizers and participants agree that, in addition to initiating undergraduate students in scientific research, these meetings help to bolster the tutoring skills of young medical academicians and also to stimulate undergraduates to pursue future academic careers. Furthermore, the scientific production that emerges from these meetings, once published in peer reviewed journals, may increase visibility of the medical school nationally and internationally and facilitate fundraising for other research projects.

There are several papers in literature regarding the rate of full paper peer reviewed publications originated from abstracts presented at Professional Societies' Medical Meetings and described rates ranging form 35 to $65 \%^{1-3}$. The Undergraduate Medical Congress of ABC (COMUABC) was founded in 1976 by Nylceo Marques de Castro Medical Student Union for development of scientific research conducted by medical students from the ABC Foundation School of Medicine. In this paper we evaluated the scientific impact of this yearly event.

\section{Methods}

We have accurate and systematic information on all papers presented over the last seven years when this annual event was held. We initially conducted a retrospective search looking for all papers registered for oral presentation from 2002 to 2007 in the records of the COMUABC, available in the indexed quarterly journal Arquivos Médicos do ABC - ABC Medical Archives (ISSN 0100-3992). Afterwards, a second retrospective search

\footnotetext{
1. Médico da Faculdade de Medicina do ABC, Santo André, SP

2. Estudantes de Medicina pela Faculdade de Medicina do ABC, Santo André, SP

3. Médico do Hospital Israelita Albert Einstein, São Paulo, SP
} 
covering six years (2002-2007) of the awards bestowed during each COMUABC was undertaken in the congress registry books. Papers awarded by the scientific committees were identified. Then, we searched for the publication status of these papers in the Medline (Pubmed) and Lilacs (Literatura Latino-americana e do Caribe em Ciências da Saúde - Latin American and Caribbean Health Science Literature Database) databases by the title and author's name.

Finally, in an attempt to avoid an underreporting bias in the results and to identify all instances of publication including both foreign and national abstracts in the annals of other scientific medical meetings, a more extensive search was made of the online curriculum vitae (available on the Lattes Platform) of the teachers who coauthored the papers. The Lattes Platform contains the structured curriculum vitae of Brazilian scientists, publicly available on the internet (http://lattes.cnpq.br).

\section{Statistical aspects:}

For univariate analysis, a Chi-square test was used, or a Fisher's exact test, when applicable. For the multivariate model, logistic regression was used. Variables with a significance level equal to or lower than 0.1 in univariate analysis were evaluated by multivariate analysis. . A p value of lees than 0.05 was considerd significant.

\section{Inclusion criteria:}

A paper was considered published when its abstract appeared in indexed journals that were retrievable in the Lilacs or Medline databases, in the registries of scientific meetings of national or international medical specialty organizations, or cited in the curriculum vitae (found on the Lattes Platform) of teachers who coauthored the papers.

\section{RESULTS}

From 2002 to 2007,408 papers were submitted for oral presentation and 71 papers were awarded (17.4\%) by the scientific committees. The total number of papers published was $138(33.8 \%)$, of which $33(8.1 \%)$ were listed in Medline, $57(14 \%)$ in Lilacs and $48(11.7 \%)$ in the annals of other scientific meetings of national or international medical specialty organizations. Figure 1 shows the number of submissions and publications per year during the study period. In Figure 2 we show the number of papers selected for awards and among these those that were eventually published.

From 2002 to 2007, analyzing all papers $(\mathrm{N}=71)$ selected for award, 34 (47.9\%) were published, whereas 104 (30.9\%) of those not selected $(N=337)$ were published $(p=0.008)$. In the logistic regression model, having been selected for an award was an independent factor for later publication (OR: 2.05, 95\% Cl 1.22-3.46; $p=0.006$ ).

Regarding publication in journals indexed in Medline (Pubmed), of the studies that received an award by the academic congress scientific committee $(N=71)$, the percentage of publication was $15.4 \%$, whereas, of the studies that were not awarded $(\mathrm{N}=337)$, the percentage of publication was $6 \%(p=0.02)$. In the multivariate model, receiving an award was also an independent factor for publication in journals indexed in this database (OR: 2.62 95\% Cl 1.21-5.69;
Figure 1 - Characteristics of the analyzed papers

Papers submitted and published by year (2002-2007)

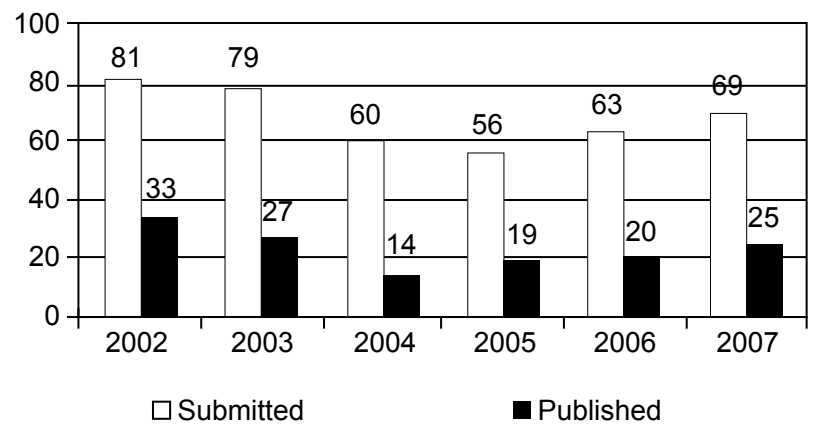

Figure 2 - Papers awarded and published aftewards

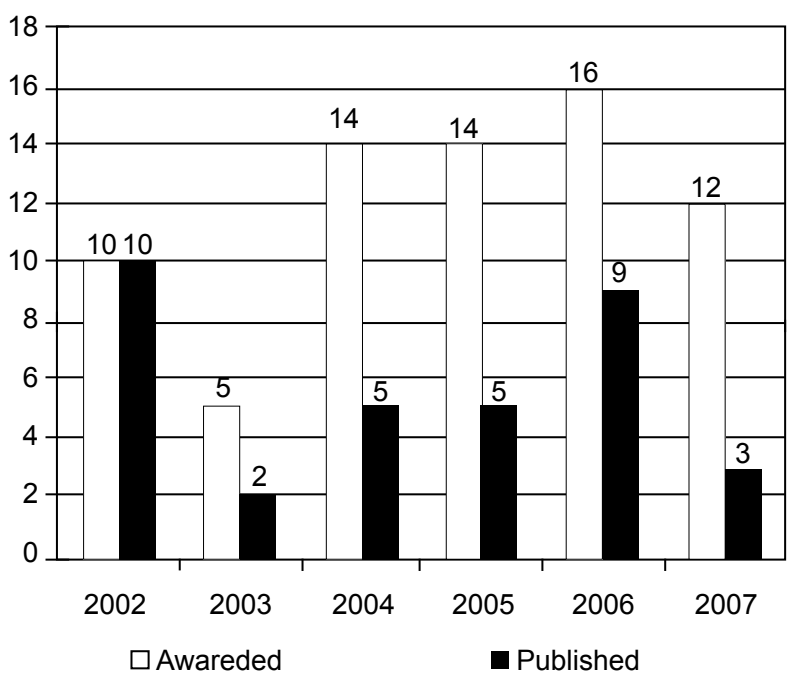

$p=0.01$ ) (Table 1 ). Table 1 shows the influence of receiving an award at the meeting on the possibility of future publication in Medline and Lilacs databases.

\section{Scientific productivity areas in the institution}

$P$ apers submitted and published were classified by category and discipline or specialty and results are shown in Tables 2 and 3 , respectively.

Table 2 shows that categories with the highest rate of publication by the number of those submitted were clinical papers, with a rate of $49 \%(26 / 53)$, and epidemiology papers, with $48.8 \%(42 / 86)$.

Specialties (Table 3) or disciplines that submitted the most papers were Biochemistry, Orthopedics, Digestive System Surgery and Oncology. In general publications, specialties that 
Table 1 - Publications (\%) according to receiving or not an award by the academic congress scientific committee in the period from 2002 to 2007

\begin{tabular}{|c|c|c|c|}
\hline Award in COMUABC (N) & Publications (\%) & Univariate Analysis* & Multivariate Analysis $(95 \% \mathrm{Cl}) * *$ \\
\hline $\begin{array}{l}\text { Paper awarded } \\
(N=71)\end{array}$ & $47.9 \%$ & $p=0.008$ & $\begin{array}{c}\text { OR: } 2.05 \text { 95\% IC 1.22-3.46; } \\
p=0.006\end{array}$ \\
\hline $\begin{array}{l}\text { Paper not awarded } \\
(N=337)\end{array}$ & $30.9 \%$ & - & - \\
\hline Award in COMUABC (N) & Publications in Pubmed (\%) & Univariate Analysis* & Multivariate Analysis $(95 \% \mathrm{Cl})^{\star *}$ \\
\hline $\begin{array}{l}\text { Paper awarded } \\
(N=71)\end{array}$ & $15.4 \%$ & $p=0.02$ & $\begin{array}{c}\text { OR: } 2.6295 \% \mathrm{Cl} 1.21-5.69 \\
p=0.01\end{array}$ \\
\hline $\begin{array}{l}\text { Paper not awarded } \\
(N=337)\end{array}$ & $6.0 \%$ & - & - \\
\hline Award in COMUABC (N) & Publications in Lilacs (\%) & Univariate Analysis* & Multivariate Analysis (195\% CI) \\
\hline $\begin{array}{l}\text { Paper awarded } \\
(N=71)\end{array}$ & $16.0 \%$ & $p=0.45$ & $N A^{* * *}$ \\
\hline $\begin{array}{l}\text { Paper not awarded } \\
(N=337)\end{array}$ & $13.0 \%$ & - & - \\
\hline
\end{tabular}

${ }^{*}$ Chi-square test ${ }^{* *}$ Logistic Regression Model ${ }^{* * *}$ Did not achieve statistical relevance

\begin{tabular}{lcc}
\hline \multicolumn{3}{c}{$\begin{array}{c}\text { Table 2 - Papers registered and published by category } \\
\text { during the period of 2002-2007 }\end{array}$} \\
\hline Category & Registered & Published \\
Basic-experimental & 27 & 11 \\
Surgery & 60 & 16 \\
Internal Medicine & 53 & 26 \\
Epidemiology & 86 & 42 \\
Monograph & 58 & 9 \\
Case report & 124 & 34 \\
Specialty/Discipline & Registered & Published \\
Oncology & 31 & 27 \\
Biochemistry & 36 & 15 \\
Urology & 21 & 13 \\
Digestive System Surgery & 32 & 11 \\
Orthopedics & 35 & 10 \\
Thoracic Surgery & 18 & 7 \\
\hline
\end{tabular}

published the most were Oncology, Biochemistry and Urology. Publication rates for such specialties were $87 \%(27 / 31)$ for Oncology, 61\% (13/21) for Urology and 41\% (15/36) for Biochemistry.

\section{Discussion}

Comparing two five year periods 1981-1985 and 19972001 , national Brazilian scientific production increased fourfold (Medline), with a growth of 5.3 times in the percentage of cited papers and 1.8 in the impact factor of publications ${ }^{1,2}$. Recent studies ${ }^{1,3,4}$ have shown that, in the last decade, academic research has helped place Brazil among the twenty most productive countries in health sciences worldwide. Growth in volume of publication of the twenty universities that most appeared in the Medline database in the three year periods of $1998-2000$ and 2001-2003, ranged from $15 \%$ to $231 \%{ }^{1,2}$.

It is also noteworthy that auditing of all post-graduate medical science programs by the Brazilian government agency CAPES may have enhanced scientific quality. Indeed, from 2004 to 2006, CAPES took into account five criteria for evaluation $^{5}$ : I - post-graduate program proposal; II - academic level of the teaching staff; III - student theses and dissertations; IV - intellectual production; and V - social inclusion. Careful analysis of the integral text ${ }^{5-8}$ allows one to observe that all of these criteria reflect the publication of papers in indexed databases such as Lilacs and Medline. It is important to stress that for criterion II (academic staff) additional points are awarded for participation of undergraduate students in scientific research, since they may become post-graduate students in the future ${ }^{5}$.

There is growing pressure in the academia for publications ${ }^{1}$. For the professor, this situation demands greater participation in undergraduate and postgraduate research. For the undergraduate student, participation in these research activities translates into a competitive advantage useful for example, in the future selection process for medical residency ${ }^{-11}$. 
From an educational perspective, relevance of scientific research performed by undergraduates has been stressed by several authors ${ }^{8-15}$. Taking part in research at the undergraduate level promotes direct contact of students with the original medical-scientific thinking process, which in turn helps them to better assimilate further scientific knowledge ${ }^{12-14}$. Because of the current speed with which medical knowledge is produced and recycled, as well as the exponential increase in available information, it is important for the young professional to learn how to best integrate new evidence obtained from research in which he/she is involved, into the practice of medicine in an orderly fashion. Furthermore, enrolling in a research project and going through the entire process - from gathering data to discussion, writing and presentation of a paper - will educate a young physician to better read a scientific paper, reflect on and criticize results and perhaps become a future researcher ${ }^{13-15}$.

It appears that undergraduate medical meetings involving both professors and students can be an important tool for enhancement of their scientific production. Furthermore, granting of awards and constructive criticism of the best papers presented at meetings may also increase the chances of publication.

Areas in which our study showed a larger scientific production are in agreement with Guimarães et al., who reported in $2004^{7}$ that the specialties of Oncology, Biochemistry and Urology were among the fields of largest national scientific productivity in Medicine and Health over the last decade.

Our results show a lower rate of peer review journal publication of the abstracts presented at our Medical Student Meetings than that seen at meetings of practicing physicians, which range from 35 to $65 \%^{1-3}$. Possible reasons may include: 1) a higher quality of abstracts originated from established researchers who attend meetings of professional societies and 2) our attempt to be all inclusive and register many of the abstracts presented by our students to give them the opportunity of presenting their findings thereby decreasing the percentage of published papers.

It appears that undergraduate medical meetings involving both professors and students can be an important tool for the enhancement of their scientific production. Furthermore, the granting of awards and constructive criticism of the best papers presented at the meetings may also increase the chances of publication of these papers. It is however, likely that Undergraduate Medical Meetings may only publicize to the academic community and grant awards to the best research that is already underway at a particular Institution. Nevertheless, such meetings may also stimulate medical students to search for and strive to be included in the best and most productive scientific groups already working at a particular Institution.

\section{CONCLUSION}

We believe that it is possible to conduct quality scientific research with undergraduate students and that an undergraduate medical meeting may be an appropriate stimulus as well as a useful platform for this activity to appeal to undergraduate medical students.

\section{Acknowledgements}

We thank the Directors of the $34^{\text {th }}$ Academic Congress of $A B C$ for granting access to the registry books. Our sincere thanks also to Rafael Rodrigues de Miranda and Elaine Gorobets, Vice-President and Secretary-General of the $34^{\text {th }}$ Academic Congress of $\mathrm{ABC}$.

\section{Conflict of interest: none}

\section{Resumo}

Experiência do Congresso Médico UniversitáRIO da Faculdade de Medicina da Fundação ABC

OBJetivo. Quantificar e descrever o número de trabaIhos premiados e não premiados em apresentação oral no Congresso Médico Universitário do ABC no período de 2002 a 2007, que obtiveram posterior publicação em revistas científicas, a fim de avaliar se o trabalho premiado teria maior potencial para publicação. Mapear áreas por produtividade científica na instituição.

Métodos. Busca retrospectiva dos trabalhos inscritos no período de 2002 a 2007 que obtiveram publicação em periódicos indexados nas bases de dados Medline (Pubmed) e Lilacs ou em anais de congressos científicos de especialidades nacionais ou internacionais.

RESULTADOS. Entre 2002 e 2007, foram inscritos 408 trabaIhos e 71 foram premiados. O total de trabalhos publicados foi de 138 (33,8\%), sendo 8,1\% na base Medline, 14\% na base Lilacs e 11,7\% encontrados a partir da plataforma Lattes. Premiação pela banca examinadora foi variável independente para publicação (OR: 2,05 IC95\% 1,22-3,46; $p=0,006$ ) assim como para publicação na base Medline (OR: 2, 62 IC95\% $1,21-5,69 ; p=0,01)$.

Conclusão. O papel de alunos de graduação na produção científica institucional refletido na produção de um Congresso Médico Universitário é relevante e deve continuar a ser estimulado. [Rev Assoc Med Bras 2010; 56(3): 313-7]

Unitermos: Congressos. Publicações. Resumos de reunião. Pesquisa.

\section{REFERENCES}

1. Valderrama-Zurián JC, Bolaños-Pizarro M, Bueno-Cañigral FJ, Alvarez FJ, Ontalba-Ruipérez JA, Aleixandre-Benavent R. An analysis of abstracts presented to the college on problems of drug dependence meeting and subsequent publication in peer review journals. Subst Abuse Treat Prev Policy. 2009; 4:19

2. Hoeg RT, Lee JA, Mathiason MA, Rokkones K, Serck SL, Crampton KL, Emmel $A E$, Severson EA, Go RS. Publication outcomes of phase II oncology clinical trials. Am J Clin Oncol. 2009:32:253-7.

3. De Bellefeuille C, Morrison CA, Tannock IF. The fate of abstracts submitted to a cancer meeting: factors which influence presentation and subsequent publication. Ann Oncol. 1992;3:187-91.

4. Deheinzelin D, Caramelli B. Produção científica, pós-graduação e a RAMB. Rev Assoc Med Bras. 2007;53:471-2.

5. Guimaraes J. A pesquisa médica e biomédica no Brasil: comparações com o desempenho científico brasileiro e mundial. Ciênc Saúde Coletiva. 2004;9:303-27.

6. Zorzetto R. The scientific production in health and biological sciences of the top 20 Brazilian universities. Braz J Med Biol Res. 2006;39:1513-20.

7. Goldani MZ, Gurgel RQ, Blank D, Gerolin J, Mari JJ. Pursuing efficiency: international visibility of the scientific production of Brazilian graduate programs in child and adolescent health from 1998 through 2003. J Pediatr (Rio J). 2007:83:436-40

8. Avaliação trienal (2004-2007) da Grande Área Ciencias da Saúde. Brasília (DF): Fundação Coordenação de Aperfeiçoamento de Pessoal de Nível Superior. [citado 12 fev 2009]. Disponível em: http://www.capes.gov.br/ images/stories/download/avaliacao/CA2007_CienciasSaude.pdf. 
9. Avaliação da Pós Graduação da Faculdade de Medicina do ABC. Brasília (DF): Fundação Coordenação de Aperfeiçoamento de Pessoal de Nível Superior. [citado 12 fev 2009]. Disponível em: http://conteudoweb.capes.gov.br/ conteudoweb/VisualizadorServlet?nome=33112010/015/2003_015_331 12010001 P5_Ficha.pdf\&aplicacao $=$ avaliacaotrienal\&idEtapa $=\overline{2} 2 \& a \bar{n} 0=2$ $003 \&$ tipo $=$ divulga.

10. Ficha de avaliação do programa de mestrado da Faculdade de Medicina do ABC. Brasília (DF): Fundação Coordenação de Aperfeiçoamento de Pessoal de Nível Superior. [citado 12 fev 2009]. Disponível em: http://conteudoweb. capes.gov.br/conteudoweb/VisualizadorServlet?nome $=33112010 / 015 / 20$ 06_015_33112010001P5_Ficha.pdf\&aplicacao=avaliacaotrienal\&idEtap $a=\overline{2}$ ano $=2006 \&$ tipo $=$ divūlga.

11. De Meis L. The growing competition in Brazilian science: rites of passage, stress and burnout. Braz J Med Biol Res. 2003;36:1135-41.

12. Goldstein JL, Brown MS. The clinical investigator: bewitched, bothered, and bewildered -- but still beloved. J Clin Invest. 1997;99:2803-12.

13. Csillag $C$, Schor N. O pesquisador-médico: da academia às parcerias. Rev. Assoc Med Bras. 1999;45:152.
14. Zemlo TR, Garrison HH, Partridge NC, Ley TJ. The physician-scientist: Career issues and challenges at the year 2000. FASEB J. 2000;14:221-30.

15. Timothy J, Rosenberg E. The physician-scientist career pipeline in 2005: Build It, and They Will Come. JAMA. 2005;294:1343-51.

16. Rosenberg W, Donald A. Evidence based medicine: an approach to clinical problem solving. BMJ. 1995;310:1122-6.

17. Lopes AA. Medicina baseada em evidências: a arte de aplicar o conhecimento científico na prática clínica. Rev Assoc Med Bras. 2000;46:285-8.

18. Evans S, Deeks J, Duley L, Ruairidh M, Goodman NM. Does research make better doctors? Lancet. 1994;343:58-9.

Artigo recebido: 29/11/09

Aceito para publicação: 24/03/10 